Research Article

\title{
Does Off-Farm Work Improve Farm Income? Empirical Evidence from Tolon District in Northern Ghana
}

\author{
Benjamin Tetteh Anang $(\mathbb{D}$, Kwame Nkrumah-Ennin, and Joshua Anamsigiya Nyaaba
}

Department of Agricultural Economics and Extension, Faculty of Agriculture, University for Development Studies, Tamale, Ghana

Correspondence should be addressed to Benjamin Tetteh Anang; benjamin.anang@uds.edu.gh

Received 3 October 2019; Revised 30 June 2020; Accepted 25 August 2020; Published 7 September 2020

Academic Editor: Othmane Merah

Copyright $(92020$ Benjamin Tetteh Anang et al. This is an open access article distributed under the Creative Commons Attribution License, which permits unrestricted use, distribution, and reproduction in any medium, provided the original work is properly cited.

\begin{abstract}
Participation of farm households in off-farm work has gained prominence in recent times as an income diversification strategy. The effect of off-farm work on farm income is however unclear. This paper therefore sought to provide empirical evidence of the income effect of off-farm activity participation using a cross section of maize farmers in Tolon District of Ghana as a case study. In order to account for sample selection bias, the Heckman selection model was used to estimate the factors influencing participation in off-farm work and the determinants of farm income. Furthermore, the study employed propensity score matching to evaluate the impact of off-farm work on farm income. The results indicate that participation in off-farm work is influenced by sex, age, and years of formal education of the respondent, farm size, and number of dependents while farm income is influenced by age of the respondent, farm size, and access to credit. In addition, the result of the propensity score matching revealed that participants in off-farm work increased their farm income by at least GH\$ 1702 as a result of income diversification. The rural economy therefore provides off-farm and on-farm linkages that enhance farmers' income from agriculture. The creation of employment opportunities outside the farm will therefore complement on-farm work and enhance income from farming.
\end{abstract}

\section{Introduction}

Most developing countries including Ghana depend on agriculture as an importance source of livelihood. It is estimated that in Ghana, more than 60 percent of the population are engaged in agriculture as a source of livelihood [1]. Majority of the farmers are smallholders who cultivate less than 2 hectares of farm land [2] and account for about 80 percent of the food produced locally [3]. Yields of most crops are generally below achievable levels due to reliance on natural rainfall for production, low adoption of improved production technologies, and lack of access to services such as agricultural extension and farm credit. In response to liquidity constraints and declining farm incomes, many smallholders diversify production and have multiple sources of income apart from farming, which have implications for agricultural productivity and farm income.
According to the existing literature, there is increasing recognition of the role that off-farm work plays particularly in smallholder agriculture in developing countries [4]. For most agrarian communities, farming is considered as the main occupation. Off-farm work is thus any activity undertaken by the farmer or farm household outside farming as an additional source of income. This is opposed to nonfarm work which relates to all activities that are not related to farming (such as dressmaking and commerce). Hence, offfarm work includes farm-related activities carried out by farm households for income such as exchange of labour for cash on another farmer's farm. The major sources of offfarm income in Ghana include commerce, agroprocessing, charcoal production, seasonal migration, brewing of local gin, basketry, and collection and sale of firewood $[4,5]$. According to Chang and Wen [6], participation in off-farm work by farm households is a persistent phenomenon globally, with a steady increase in the dependence of farm 
families on income from off-farm work. Income from offfarm work is regarded as an important source of livelihood for farm households and a means to diversify household income source. A study in rural Ghana by Jolliffe [7] indicated that about $74 \%$ of Ghanaian farm households participated in off-farm work. Also, research showed that, on average, $65 \%$ of American farm households were engaged in off-farm work [8]. Chang and Wen [6] also reported that about $75 \%$ of Taiwanese farm households earned off-farm salaries.

The increasing importance of off-farm work to farm households' economic well-being has generated a lot of discussion among researchers regarding the role off-farm work plays in household welfare, especially in terms of food security, agricultural productivity, and household income. It is a commonly held view that participation in off-farm work is expected to reduce on-farm labour availability and its allocation and thus constrain agricultural productivity. On the contrary, it is also believed that off-farm work enables farm households to stabilize household income and reduce vulnerability and uncertainties associated with agricultural production. As indicated by the extant literature, participation in off-farm work has two effects on production: a negative lost-labour effect and a positive income or liquidityrelaxing effect [9]. The lost-labour effect occurs when the household loses farm labour to off-farm activities, while the income effect occurs when the household earns income from off-farm activities which it can invest into farming. The effect of off-farm work on farm income will however depend on which of the two effects is stronger.

Off-farm work as a risk management tool that reduces income variability of farm households has been reported by some authors [10,11]. As demonstrated by Mishra and Goodwin [12], farm households may depend on off-farm work to stabilize household income because farm commodity prices are more variable than off-farm wages. It is expected from the theory of production that a risk-averse farmer will choose to allocate labour and other resources to activities that are less risky to the point where the expected marginal returns are equal for the different activities. The higher variability in farm commodity prices is therefore expected to drive participation in off-farm work.

An earlier study by Lanjouw [13] noted that the rise in off-farm activity by farm households is as a result of declining farm incomes and the need to safeguard against production risks. This finding is corroborated by a recent study by Akinrinde et al. [14] which indicated that declining farm income is the main reason for income diversification among Nigerian farmers. Alasia et al. [15] on the other hand view participation in off-farm work as a form of self-insurance which enables farm households to stabilize household income.

Several studies allude to a positive effect of off-farm work on agricultural productivity, food security, and household income of farm households [16-18]. For most farm households, farm income constitutes a significant part of the total household income. A policy question which is relevant to most rural farm households is whether or not off-farm work contributes directly to farm income. In other words, does income from off-farm work ease the liquidity constraints of farm households enabling greater use of farm resources in production? To the extent that farmers are able to invest earnings from off-farm activity into their farm business, farm output and productivity are expected to grow and exert a positive influence on farm income.

This study is motivated by the lack of empirical evidence of the effect of off-farm work on farm income of smallholder farmers in Ghana. The objective of this paper is therefore to assess the contribution of off-farm work to farm income in Tolon District of Ghana. The paper contributes to the literature on income diversification and its effects on household welfare by empirically estimating the magnitude and direction of impact of off-farm work on farm income of smallholder farmers.

The rest of the paper is structured as follows. Section 2 describes the methods used in the study, which provides a background of the study area, sampling and data collection, and method of data analysis and data description. Section 3 presents the results and discussion of the major findings of the study. The conclusion and recommendations from the study are provided in Section 4.

\section{Materials and Methods}

2.1. Study Area and Sampling. The study was conducted in the Tolon District of the Northern Region of Ghana. The area is part of the northern savannah zone of Ghana and is well known for its agricultural production. The area experiences a single rainfall regime per annum and is known for the cultivation of crops such as rice, maize, and groundnut, which are important staples. The population of the district stood at 72,990 according to the 2010 Population and Housing Census (PHC). An estimated $92 \%$ of the population are engaged in agriculture.

Three communities, namely, Nyankpala, Dundo, and Gbushalagu, were selected for the study due to their agricultural potential. Fifty farmers were randomly selected from each community to give a total sample of 150 farmers who were interviewed face-to-face using a semistructured questionnaire. Cochran's formula for sample size determination indicated that the number of farmers selected for the study is a representative sample. In the absence of a welldefined sample frame, households were selected at random in each community by taking into account the distribution of households. Information solicited from farmers included individual, household and farm characteristics, production activities, production costs and returns, and access to production resources and services.

2.2. Empirical Models. Participation in off-farm work and the factors determining farm income were analysed empirically using the Heckman Selection Model, while a nonparametric treatment effect model was used to estimate the effect of off-farm work on farm income. The Heckman selection model can be estimated using either maximum likelihood or a two-step approach. This study adopted the maximum likelihood approach because it overcomes some 
of the limitations associated with the two-step approach such as the possibility of the correlation factor to lie outside the prescribed range. Methodologically, endogenous switching regression is an alternative approach for estimating the income effect of off-farm work. However, the Heckman selection model was preferred because it provided a better fit of the data.

2.2.1. Heckman Selection Model. Estimation of the Heckman selection model entails the estimation of a selection equation (off-farm participation model) using either probit or logit model followed by estimation of an outcome equation (farm income model) using least squares regression while accounting for sample selection bias. The assignment of households into participants and nonparticipants in offfarm work is nonrandom. Hence, OLS regression will not provide consistent parameter estimates of the outcome equation. To address this problem, there is the need to construct a correction factor, otherwise known as the inverse Mill's ratio, which is appended to the outcome equation as an additional explanatory variable.

The choice to participate in off-farm work can be estimated using a probit model which is specified as follows:

$$
Z_{i}^{*}=\gamma^{\prime} x_{i}+u_{i},
$$

where $Z_{i}^{*}$ is a latent variable which measures the probability that the $i^{\text {th }}$ household participates in off-farm work, such that the observed variable $Z_{i}=1$ if the household participates in off-farm work and $Z_{i}=0$ if otherwise, $x_{i}$ indicates a vector of exogenous factors influencing $Z_{i}^{*}$, and $\gamma$ represents a vector of parameters to be estimated.

In the second stage analysis, the amount of farm income $\left(Y_{i}\right)$ is regressed on a set of exogenous factors, $w_{i}$, for all situations where the selection equation equals one $\left(Z_{i}=1\right)$, using the estimated inverse Mill's ratio as an additional explanatory variable.

Hence, given that $Z_{i}=1$, we have the following:

$$
Y_{i}=\beta^{\prime} w_{i}+v_{i},
$$

where $Y_{i}$ indicates the amount of farm income, $w_{i}$ is a vector of variables influencing farm income, and $\beta$ is a vector of parameters to be estimated.

The error terms $u_{i}$ and $v_{i}$ have bivariate normal distributions with zero means, standard deviation $\delta_{u}$ and $\delta_{v}$, and correlation coefficient $\rho$. While $Z_{i}$ and $x_{i}$ are both observable for a random sample, $Y_{i}$ is observed only when the household participates in off-farm work $\left(Z_{i}=1\right)$. The Heckman selection model is specified as follows [19]:

$$
\begin{aligned}
E\left(Y_{i} \mid Z_{i}=1\right) & =E\left(Y_{i} \mid Z_{i}^{*}>0\right) \\
& =E\left(Y_{i} \mid u_{i}>\gamma^{\prime} x_{i}\right) \\
& =\beta^{\prime} w_{i}+E\left(v_{i} \mid u_{i}>\gamma^{\prime} x_{i}\right) \\
& =\beta^{\prime} w_{i}+\beta \sigma_{v} \lambda_{i}\left(\alpha_{u}\right),
\end{aligned}
$$

where $\lambda_{i}\left(\alpha_{u}\right)$ is the inverse Mill's ratio, which has the following specification:

$$
\lambda_{i}\left(\alpha_{u}\right)=\frac{\varphi\left(\alpha_{u}\right)}{1-\phi\left(\alpha_{u}\right)}=\frac{\varphi\left(-\alpha_{u}\right)}{\phi\left(\alpha_{u}\right)}=\frac{\varphi\left(\gamma^{\prime} x_{i} / \alpha_{u}\right)}{\phi\left(\gamma^{\prime} x_{i} / \alpha_{u}\right)},
$$

where $\varphi$ represents the normal density function while $\phi$ indicates the normal distribution function.

As indicated by Heckman [19], when there is sample selection bias, an ordinary least squares (OLS) regression without the inverse Mill's ratio will lead to inconsistent parameter estimates. Thus, for this study, OLS regression of $Y_{i}$ on $w_{i}$ without the correction factor or inverse Mill's ratio $\left(\lambda_{i}\left(\alpha_{u}\right)\right)$ will lead to inconsistent $\beta$ estimates. Consequently, the inverse Mill's ratio was included as an additional explanatory variable in the outcome equation (equation (2)).

The identification criterion requires that at least one variable which influences participation in off-farm work but not farm income is included in the model. The number of dependents was chosen as an exclusion variable. This is because the number of dependents has a direct influence on participation in off-farm work, particularly on the number of hours worked but does not directly influence farm income. The choice of number of dependents as an exclusion variable is supported by Anang [20] who used the dependency ratio as an exclusion variable in a study on the effect of off-farm work on agricultural productivity in northern Ghana.

\subsubsection{Propensity Score Matching: Estimating the Effect of Off-} Farm Work on Farm Income. Impact evaluation studies in the extant literature have relied on estimation of average treatment effects as direct measures of the impact of interventions in the agricultural and other sectors. The effect of an intervention or exposure on those who received the treatment is an important measure in impact evaluation studies. Thus, to quantify the effect of off-farm work on farm income, we estimated the average treatment effect on the treated (ATT). The average treatment effect (ATE) given the observable data is denoted by

$$
\mathrm{ATE}=E\left(Y^{1} \mid T=1\right)-E\left(Y^{0} \mid T=0\right),
$$

where $Y^{1}$ is the farm income of individuals who participated in off-farm work and $Y^{0}$ is the farm income of nonparticipants in off-farm work, $T=1$ represents the farmers who participated in off-farm work (referred to as the treated), and $T=0$ represents nonparticipants in off-farm work (referred to as the untreated or control). According to [21], $E\left(Y^{1} \mid T=\right.$ 1) $-E\left(Y^{0} \mid T=0\right)$ is equal to zero for the case of a randomised design (i.e., in the absence of selection bias). However, in the presence of selection bias, the ATE result from equation (5) provides a biased estimate of the impact of offfarm work on farm income. Hence to overcome this bias, we need to estimate the average treatment effect on the treated (ATT), using the observational data, and conditioning on a vector of farm and household characteristics $X$ as follows:

$$
\begin{aligned}
\operatorname{ATT}= & E(\Delta \mid X, T=1)=E\left(Y^{1}-Y^{0} \mid X, T=1\right)=E \\
& \left(Y^{1} \mid X, T=1\right)-E\left(Y^{0} \mid X, T=1\right) .
\end{aligned}
$$


However, the counterfactual $E\left(Y^{0} \mid X, T=1\right)$ is unobservable, hence assumptions are made to estimate it as follows: $E\left(Y^{0} \mid X, T=1\right)=E\left(Y^{0} \mid X, T=0\right)$. Thus, the ATT equation becomes

$$
\begin{aligned}
\mathrm{ATT} & =E(\Delta \mid X, T=1)=E\left(Y^{1}-Y^{0} \mid X, T=1\right) \\
& =E\left(Y^{1} \mid X, T=1\right)-E\left(Y^{0} \mid X, T=0\right) .
\end{aligned}
$$

2.3. Sampling Procedure and Sources of Data. The data for the study were collected from smallholder maize farmers in 3 communities in the Tolon District of Northern Ghana. Fifty farmers were selected from each community to give a total sample of 150 . The communities and respondents were randomly selected. Face-to-face interviews were carried out with each respondent using semistructured questionnaire. The questionnaire contained both open- and close-ended questions. The questions covered farm, household and institutional factors, and off-farm and production decisions, among others.

\subsection{Description and Expected Signs of the Explanatory} Variables. The description and expected signs of the variables included in the analysis are provided in Table 1. Male farmers are expected to have higher farm income, but sex is hypothesized to have an indeterminate effect on participation in off-farm work. Also, older farmers are expected to be more experienced in farming and more endowed with production resources than younger farmers, which is expected to lead to a higher farm income. Older farmers, by virtue of family obligations and dependents, are expected to have higher participation in off-farm work. Education enhances employability and is therefore hypothesized to increase participation in off-farm work. At the same time, education enhances the human capital which is expected to improve farm income. Farmers with access to credit are expected to have lower participation in off-farm work since credit eases the financial burden of farm households. Credit also enhances farm production through acquisition of farm inputs and financing of farm operations, which is expected to enhance farm profits. Farmers with large farms are expected to be progressive farmers and better-off compared to those with small farm holdings, leading to less participation in off-farm work and higher farm income. In addition, a higher number of dependents implies greater financial burden on households hence higher likelihood to take part in off-farm work. However, the number of dependents is not expected to have any direct effect on farm income.

\section{Results and Discussion}

3.1. Characteristics of the Respondents. We first describe the characteristics of the sample as shown in Table 2. The respondents have an average age of 38 years and 6.5 years of formal education. The respondents are therefore in their youthful age, a situation which is conducive for agricultural production. This is because agriculture in most developing countries, including Ghana, involves a lot of drudgery. The respondents however have low level of education, a situation which can negatively affect uptake of innovation and ability to access and use information for agricultural production. Also, the respondents have an average household size of 9 and 3 dependent members and possess 2.7 hectares of land for agricultural production out of which 2 hectares is allocated to maize production. This shows that maize production is an important economic activity among rural dwellers. In Ghana, farm households depend on maize for food and income. Close to 43 percent of the respondents participated in off-farm work while 46 percent used credit in farming. In addition, 58 percent of the respondents are male indicating lower female participation in maize cultivation. Maize is a food security crop and household heads, most of whom are male, are anticipated to engage in its cultivation for home consumption and cash sales. On average, farmers' gross income from maize cultivation was GHథ 2599 (approximately US\$ 490).

Table 3 presents the distribution of farmers' gross income from maize cultivation. Majority (76\%) of the farmers obtained up to GHÆ 2500 as gross income from farming. The figure is very low, considering that maize is the most dominant crop grown by nearly every household in northern Ghana due to its important as a staple crop and also as cash crop for large scale producers. Participants in off-farm work had higher farm income compared with nonparticipants.

3.2. Results of the Heckman Selection Model. The results of the Heckman selection model are presented in Table 4. The log-likelihood ratio (LR) test is significant at $1 \%$ indicating the presence of selection bias, which justifies the use of the Heckman model to correct for the bias. In other words, estimating separate equations for the selection and outcome models would result in biased estimates.

\subsubsection{Factors Influencing Participation in Off-Farm} Activities. The estimates of the factors influencing participation in off-farm work using the Heckman selection model are presented in Table 4 . The study indicates that the likelihood of maize farmers to participate in off-farm work is affected by age, sex, education, and total agricultural land.

Participation in off-farm work is higher for women. Women play several roles in the household apart from farming. They are involved in petty trading, arts, and craft and are more disposed to take up extra income earning activity to support the household's income. The marginal effect of sex indicates that the probability of women engaging in off-farm work is 0.214 higher than men. Ahmed and Melesse [22] as well as Man and Sadiya [23] obtained similar results in their studies in eastern Ethiopia and Malaysia, respectively. As observed by Ahmed and Melesse [22], female-headed households were more likely to engage in off-farm work compared with male-headed households because female-headed families take part in off-farm work to offset their relative lower farm income compared with maleheaded families. The result however disagrees with the findings of Pramanik et al. [24] in their study on the rural 
TABLE 1: Description and expected signs of the explanatory variables included in the analysis.

\begin{tabular}{lccc}
\hline Variable & Description & Expected sign \\
\hline Sex & Dummy = 1 if farmer is male; 0 otherwise & Model 1 & + \\
Age & Age of farmer in years & + & + \\
Education & Years of formal education & + & + \\
Credit access & Dummy = 1 for credit access; 0 otherwise & - & + \\
Maize farm size & Maize farm size in hectares & + & + \\
Dependents & Number of dependents & NA \\
\hline
\end{tabular}

1 US\$ $=5.4$ Ghana Cedis (GH\$). Model 1 is the probit participation model. Model 2 is the farm income (outcome) equation.

TABLE 2: Descriptive statistics of the variables used for the analysis.

\begin{tabular}{|c|c|c|c|c|c|c|c|}
\hline \multirow{2}{*}{ Variable } & \multicolumn{2}{|c|}{ Full sample } & \multicolumn{2}{|c|}{ Participants } & \multicolumn{2}{|c|}{ Nonparticipants } & \multirow{2}{*}{ Mean diff. ${ }^{\dagger}$} \\
\hline & Mean & S. D. & Mean & S. D. & Mean & S. D. & \\
\hline Farm income & 2599 & 3490 & 3457 & 4313 & 1962 & 2570 & $1495^{* * *}$ \\
\hline Sex & 0.58 & 0.50 & 0.52 & 0.50 & 0.63 & 0.49 & -0.11 \\
\hline Age & 38.3 & 10.5 & 37.4 & 9.43 & 39.0 & 11.3 & -1.64 \\
\hline Education & 6.47 & 6.91 & 8.48 & 7.73 & 4.98 & 5.84 & $3.50^{* * *}$ \\
\hline Maize farm size & 2.02 & 2.12 & 2.63 & 2.80 & 1.56 & 1.26 & $1.07^{* * *}$ \\
\hline Credit access & 0.46 & 0.50 & 0.47 & 0.50 & 0.45 & 0.50 & 0.02 \\
\hline Dependents & 2.80 & 2.31 & 2.17 & 2.11 & 3.27 & 2.36 & $-1.10^{* * *}$ \\
\hline
\end{tabular}

${ }^{\dagger}$ The $t$ value of the difference in means between participants and nonparticipants. ${ }^{*}$ Statistical significance at $10 \%$ level; ${ }^{* *}$ statistical significance at $5 \%$ level; ${ }^{* * *}$ statistical significance at $1 \%$ level.

TABLE 3: Distribution of gross farm income of the respondents.

\begin{tabular}{|c|c|c|c|c|c|c|}
\hline \multirow{2}{*}{ Variable } & \multicolumn{2}{|c|}{ Full sample } & \multicolumn{2}{|c|}{ Participants } & \multicolumn{2}{|c|}{ Nonparticipants } \\
\hline & Freq. & $(\%)$ & Freq. & $(\%)$ & Freq. & $(\%)$ \\
\hline Up to 2,500 & 114 & 76.0 & 43 & 67.2 & 71 & 82.5 \\
\hline $2,501-5,000$ & 23 & 15.3 & 13 & 20.3 & 10 & 11.6 \\
\hline $5,001-7,500$ & 2 & 1.3 & 1 & 1.56 & 1 & 1.2 \\
\hline $7,501-10,000$ & 3 & 2.0 & 1 & 1.56 & 2 & 2.3 \\
\hline $10,001-12,500$ & 2 & 1.3 & 2 & 3.12 & 0 & 0 \\
\hline $12,501-15,000$ & 2 & 1.3 & 1 & 1.56 & 1 & 1.2 \\
\hline $15,001-17,500$ & 1 & 0.7 & 0 & 0 & 1 & 1.2 \\
\hline $17,501-20,000$ & 2 & 1.3 & 2 & 3.13 & 0 & 0 \\
\hline Above 20,000 & 1 & 0.7 & 1 & 1.56 & 0 & 0 \\
\hline Total & 150 & 100 & 64 & 100 & 86 & 100 \\
\hline Mean & 2,599 & & 4,204 & & 2,511 & \\
\hline Minimum & 140 & & 480 & & 140 & \\
\hline Maximum & 21,120 & & 21,120 & & 15,600 & \\
\hline
\end{tabular}

nonfarm economy in Bangladesh as well as Beyene [25] in a study to assess the determinants of off-farm participation decision of farm households in Ethiopia.

Younger farmers are more likely to engage in off-farm work as shown by the coefficient of the age variable. As farmers become older, they become less disposed to engage in off-farm work. Younger people are more likely to find jobs because they are more energetic. Due to the low poverty level in most rural communities, off-farm employment for rural people involves labour-intensive activities which are better suited to younger people. The quadratic term for respondent's age shows that participation in work off-farm increases at a decreasing rate with age of the farmer. The result is consistent with Pramanik et al. [24] in their study in Bangladesh as well as Bila et al. [26] in their study on the contribution of off-farm activities to farm income in Borno State, Nigeria.

Consistent with a priori expectation, the results indicate that educated farmers are more likely to work off-farm. Education enhances the human capital and opens up opportunities for employment off the farm. An additional year of education increases the likelihood of participation in offfarm work by 0.023 . The results are consistent with Matshe and Young [27] in their study on off-farm labour allocation decisions in Zimbabwe, as well as Abdulai and CroleRees [28] in their study on income diversification among households in Southern Mali. The result also agrees with Seng [29] in a study on the effect of nonfarm work on household food consumption in rural Cambodia, Pramanik et al. [24] in their study on the rural nonfarm economy in 
TABle 4: Results of the Heckman selection model of off-farm work and farm income.

\begin{tabular}{|c|c|c|c|c|}
\hline \multirow{2}{*}{ Independent variables } & \multicolumn{2}{|c|}{ Probit model } & \multicolumn{2}{|c|}{ Outcome equation } \\
\hline & Coefficient & Std. error & Coefficient & Std. error \\
\hline Sex & $-0.523^{* *}$ & 0.241 & 437.2 & 552.0 \\
\hline Age & $0.290^{* * *}$ & 0.096 & $-814.0^{* * *}$ & 223.9 \\
\hline Age squared & $-0.004^{* * *}$ & 0.001 & $12.26^{* * *}$ & 2.992 \\
\hline Education & $0.054^{* * *}$ & 0.018 & -18.41 & 37.86 \\
\hline Farm size & $0.590^{* * *}$ & 0.127 & $849.6^{* * *}$ & 150.3 \\
\hline Access to credit & -0.116 & 0.236 & $1281^{* *}$ & 541.3 \\
\hline Number of dependents & $-0.121^{* *}$ & 0.050 & & \\
\hline Constant & $-5.610^{* * *}$ & 1.901 & $14202^{* * *}$ & 4283 \\
\hline Inverse Mill's ratio $(\lambda)$ & & & $-81.68^{*}$ & 0.095 \\
\hline Rho & -0.881 & 0.079 & & \\
\hline Sigma & 2342.7 & 303.5 & & \\
\hline Lambda & -2064.7 & 423.4 & & \\
\hline Selected observations & & & & \\
\hline Unselected observations & & & & \\
\hline Wald $\operatorname{chi}^{2}(6)$ & & & & \\
\hline Prob $>$ chi $^{2}$ & & & & \\
\hline
\end{tabular}

LR test of independent equations $(\mathrm{rho}=0): \mathrm{chi}^{2}(1)=8.94, \mathrm{prob}>\mathrm{chi}^{2}=0.003$. ${ }^{*}$ Statistical significance at $10 \%$ level. ${ }^{* *}$ Statistical significance at $5 \%$ level. ${ }^{* * *}$ Statistical significance at $1 \%$ level. (6) and (1) indicate the degrees of freedom for the chi-squared estimation.

Bangladesh, and Owusu et al. [5] in their study on nonfarm work and food security in northern Ghana. McCarthy and Sun [30] estimated separate models for men and women and observed that household education levels had positive effect on both female and male participation in off-farm employment in rural northern Ghana.

Participation in off-farm work was found to be positively related to farm size and significant at $1 \%$ level. This indicates that farmers with larger agricultural lands are more likely to take up employment off the farm. The result is contrary to a priori expectation and hard to explain. A unit increase in total agricultural land increases the likelihood of working off the farm by 0.041 . The result agrees with Pramanik et al. [24] who found that farmers with larger plots were more likely to participate in nonfarm activities in Bangladesh. McCarthy and Sun [30] also observed that the size of owned land had a positive influence on participation in off-farm employment in rural northern Ghana.

The number of dependents had a negative and significant effect on participation in off-farm work, which is contrary to expectation. Households with many dependents are expected to have a higher propensity to participate in off-farm work, but the result suggests otherwise. The result is at variance with the findings of Anang [20] which indicated that an increase in the number of dependents increased the propensity of smallholder rice farmers to engage in off-farm work in northern Ghana.

3.2.2. Results of the Outcome (Farm Income) Model. The estimates of the parameters of the farm income equation using the Heckman selection model are presented in the $4^{\text {th }}$ and $5^{\text {th }}$ columns of Table 4 . The results indicate that farm income initially decreases with age of the farmer as shown by the negative coefficient of the age variable. In other words, the younger the farmer, the higher the income from maize cultivation. However, as farmers become older and gain experience in farming, their production and income increase. This is shown by the positive sign of the quadratic term of the age variable. As farmers gain experience in farming, this is expected to translate into more efficient ways of production and informed decision-making to maximise farm profits and income.

The results further indicate that the farm size variable is significant at $1 \%$ level and positively associated with farm income, which is consistent with a priori expectation. This implies that an increase in farm size results in an increase in farm income. Larger farm operators are therefore able to increase their income from farming. In addition, the study showed that the effect of credit on farm income was positive and significant at $10 \%$ level. Hence, access to credit enhanced the farm income of maize farmers in the study area. The result is consistent with a priori expectation as credit eases farm liquidity constraints and acquisition of farm inputs while enabling timeliness in carrying out farm operations to maximise output and profits.

3.3. Income Effect of Off-Farm Work. In order to quantify the income effect of off-farm work, we proceeded to estimate the average treatment effect on the treated (ATT) using the nearest neighbour and kernel matching methods (Table 5). We used the two matching methods in order to compare and check for robustness of the estimates. The results indicated that participation in off-farm work increases the farm income of participants by GHष 1702 using the nearest neighbour method and GHథ 1776 in the case of the kernelbased method. The result indicates a positive and significant effect of off-farm work on farm income. What the result implies is that participants in off-farm work are able to increase their farm income by at least $\mathrm{GH} \$ 1702$ as a result of income diversification. The result is supported by Osarfo et al. [31] who showed that participation in nonfarm work had a positive impact on the income of rural farm 
TABLE 5: Estimates of the average treatment effect of off-farm work on farm income.

\begin{tabular}{llllll}
\hline Estimation method & Treated & Control & ATT & Robust S.E. & $t$ statistic \\
\hline Nearest neighbour matching & 64 & 33 & $1701.7^{* *}$ & 737.1 & 2.309 \\
Kernel matching & 64 & 79 & $1776.3^{* * *}$ & 526.3 & 3.375 \\
\hline
\end{tabular}

Note: the outcome variable is farm income. ${ }^{* *}$ Statistical significance at $5 \%$ level. ${ }^{* * *}$ Statistical significance at $1 \%$ level.

households in the Upper East and Upper West Regions of Ghana. The important role that off-farm income plays in household income has been elaborated by other authors such as Ogbanje et al. [32] who estimated the off-farm income share of household income in North Central Nigeria at $50.28 \%$.

\section{Conclusion}

The study assessed the effect of participation in off-farm activities on farm income of maize farmers in Tolon District of Northern Ghana. Due to the problem of sample selection bias, the study employed Heckman selection model to investigate the factors influencing participation in off-farm work and the determinants of farm income, while propensity score matching was used to estimate the impact of off-farm work on farm income. The results indicated that participation in off-farm work is influenced by sex, age, and years of formal education of the respondent, farm size, and number of dependents, while farm income is influenced by age of the respondent, farm size, and access to credit. Assessment of the impact of off-farm work on farm income indicated that participants in off-farm work increased their farm income by at least $\mathrm{GH} \$ 1702$ as a result of income diversification. The rural economy therefore provides offfarm and on-farm linkages that enhance farmers' income from agriculture. The result also suggests that the negative lost-labour effect of off-farm activity participation is less than the positive liquidity (income) effect, resulting in an income gain for the farm. The study therefore concludes that participation in off-farm work enables maize farmers to improve their farm incomes, thereby improving household welfare. The creation of employment opportunities outside the farm will therefore complement on-farm work and enhance income from farming.

\section{Data Availability}

The data supporting the findings of the study are available upon request from the corresponding author.

\section{Conflicts of Interest}

The authors declare no conflicts of interest.

\section{References}

[1] Government of Ghana, The Budget Statement and Economic Policy of the Government of Ghana for the 2017 Financial Year, Ministry of Finance, Accra, Ghana, 2017, http://www.mofep. gov.gh/, 1st edition.

[2] MoFA (Ministry of Food and Agriculture), Agriculture in Ghana: Facts and Figures (2012), Ministry of Food and
Agriculture-Statistics, Research and Information Directorate (SRID), Accra, Ghana, 2013.

[3] R. E. Namara, H. Horowitz, B. Nyamadi, and B. Barry, Irrigation Development in Ghana: Past Experiences, Emerging Opportunities, and Future Directions, GSSP Working Paper No. 0027, Ghana Strategy Support Program (GSSP), Accra, Ghana, 2011, https://www.agriskmanagementforum.org/ sites/agriskmanagementforum.org/files/Documents/IFPRI\% 20-\%20Irrigation\%20in\%20Ghana.pdf.

[4] B. T. Anang, "Effect of off-farm work on agricultural productivity: empirical evidence from Northern Ghana," Agricultural Science and Technology, vol. 11, no. 1, pp. 49-58, 2019.

[5] V. Owusu, A. Abdulai, and S. Abdul-Rahman, "Non-farm work and food security among farm households in Northern Ghana," Food Policy, vol. 36, no. 2, pp. 108-118, 2011.

[6] H.-H. Chang and F.-I. Wen, "Off-farm work, technical efficiency, and rice production risk in Taiwan," Agricultural Economics, vol. 42, no. 2, pp. 269-278, 2011.

[7] D. Jolliffe, "The impact of education in rural Ghana: examining household labor allocation and returns on and off the farm," Journal of Development Economics, vol. 73, no. 1, pp. 287-314, 2004.

[8] J. Fernandez-Cornejo, Off-Farm Income, Technology Adoption, and Farm Economic Performance, Economic Research Report No. ERR-36, Economic Research Service, U.S. Department of Agriculture, Washington, DC, USA, 2007.

[9] R. O. Babatunde, "On-farm and off-farm works: complement or substitute? Evidence from Nigeria," University of Ilorin, Department of Agricultural Economics and Farm Management, Ilorin, Nigeria, Maastricht School of Management Working Paper 2015/02, 2015.

[10] H. S. El-Osta and M. J. Morehart, "Determinants of poverty among U.S. farm households," Journal of Agricultural and Applied Economics, vol. 40, no. 1, pp. 1-20, 2008.

[11] H. S. El-Osta, A. K. Mishra, and M. J. Morehart, "Determinants of economic well-being among U.S. farm operator households," Agricultural Economics, vol. 36, no. 3, pp. 291-304, 2007.

[12] A. K. Mishra and B. K. Goodwin, "Farm income variability and the supply of off-farm labor," American Journal of Agricultural Economics, vol. 79, no. 3, pp. 880-887, 1997.

[13] P. Lanjouw, The Rural Non-farm Sector in Ecuador and Its Contribution to Poverty Reduction and Inequality, World Bank, Policy Research Department, Washington, DC, USA, 1999.

[14] A. F. Akinrinde, K. F. Omotesho, and I. Ogunlade, “The issue of income diversification among rural farming households: empirical evidence from Kwara State, Nigeria," Journal of Agribusiness and Rural Development, vol. 3, no. 49, pp. 231238, 2018.

[15] A. Alasia, A. Weersink, R. D. Bollman, and J. Cranfield, "Offfarm labour decision of Canadian farm operators: urbanization effects and rural labour market linkages," Journal of Rural Studies, vol. 25, no. 1, pp. 12-24, 2009. 
[16] F. Ellis and H. A. Freeman, "Rural livelihoods and poverty reduction strategies in four african countries," Journal of Development Studies, vol. 40, no. 4, pp. 1-30, 2004.

[17] K. Gebregziabher, E. Mathijs, M. Maertens, J. Deckers, H. Bauer, and K. Gebrehiwot, "Is non-farm income relaxing farm investment liquidity constraints for marginal farms? An instrumental variable approach," International Journal of Economics and Finance Studies, vol. 4, no. 1, pp. 123-132, 2012.

[18] Y. Wang, C. Wang, and S. Pan, "The impact of nonfarm activities on agricultural productivity in rural China," in Proceedings of the AAEA \& NAREA Joint Annual Meeting, pp. 24-26, Pittsburgh, PA, USA, July 2011.

[19] J. J. Heckman, "Sample selection bias as a specification error," Econometrica, vol. 47, no. 1, pp. 153-161, 1979.

[20] B. T. Anang, Effect of Non-Farm Work on Agricultural Productivity: Empirical Evidence from Northern Ghana, WIDER Working Paper 2017/38, UNU-Wider, Helsinki, Finland, 2017.

[21] A. Dillon, Access to Irrigation and the Escape from Poverty: Evidence from Northern Mali, IFPRI Discussion Paper 00782, International Food Policy Research Institute (IFPRI), Washington, DC, USA, 2008, http://www.ifpri.org/ publication/access-irrigationand-escape-poverty.

[22] M. H. Ahmed and K. A. Melesse, "Impact of off-farm activities on technical efficiency: evidence from maize producers of eastern Ethiopia," Agricultural and Food Economics, vol. 6, no. 1, p. 3, 2018.

[23] N. Man and S. I. Sadiya, "Off-farm employment participation among rice farmers in the Muda agricultural development authority and Kemasin Semerak granary areas of Malaysia," AsiaPacific Development Journal, vol. 16, no. 2, pp. 141-153, 2009.

[24] S. Pramanik, U. Deb, and C. Bantilan, "Rural non-farm economy in Bangladesh: nature, extent, trends and determinants," in Proceedings of the 8th Conference of the Asian Society of Agricultural Economists (ASAE), Dhaka, Bangladesh, October 2014.

[25] A. D. Beyene, "Determinants of off-farm participation decision of farm households in Ethiopia," Agrekon, vol. 47, no. 1, pp. 140-161, 2008.

[26] Y. Bila, B. S. Mshelia, and J. H. Landi, "Off farm activities and its contribution to household income in Hawul Local Government Area, Borno State, Nigeria," Journal of Agriculture and Veterinary Science, vol. 8, pp. 9-13, 2015.

[27] I. Matshe and T. Young, "Off-farm labour allocation decisions in small-scale rural households in Zimbabwe," Agricultural Economics, vol. 30, no. 3, pp. 175-186, 2004.

[28] A. Abdulai and A. CroleRees, "Determinants of income diversification amongst rural households in Southern Mali," Food Policy, vol. 26, no. 4, pp. 437-452, 2001.

[29] K. Seng, "The Effects of nonfarm activities on farm households' food consumption in rural Cambodia," Development Studies Research, vol. 2, no. 1, pp. 77-89, 2015.

[30] N. McCarthy and Y. Sun, "Participation by men and women in off-farm activities: an empirical analysis in rural Northern Ghana," in Proceedings of the International Association of Agricultural Economists Conference, Beijing, China, August 2009.

[31] D. Osarfo, B. Senadza, and E. Nketiah-Amponsah, "The impact of nonfarm activities on rural farm household income and food security in the Upper East and Upper West Regions of Ghana," Theoretical Economics Letters, vol. 6, no. 3, pp. 388-400, 2016.

[32] E. C. Ogbanje, S. A. N. D. Chidebelu, and N. J. Nweze, "An evaluation of off-farm work and household income among small-scale farmers in North Central Nigeria," Journal of Agriculture and Sustainability, vol. 7, no. 2, pp. 227-244, 2015. 